\title{
Effect of Molar Concentration on Structural, Morphological and Optical Properties of CdO Thin Films Prepared by Chemical Bath Deposition Method
}

\author{
Sibel MORKOÇ KARADENIZ1*
}

\begin{abstract}
Cadmium Oxide (CdO) thin films were grown on Indium Tin Oxide (ITO) coated glasses by Chemical Bath Deposition (CBD) technique. The concentration of aqueous bath was varied between $0.03 \mathrm{M}$ and $0.05 \mathrm{M}$. The films were annealed at $400{ }^{\circ} \mathrm{C}$ for $2 \mathrm{~h}$. Structural, morphological and optical properties of the $\mathrm{CdO}$ thin films were investigated with XRD, SEM and Uv-Vis measurements. Additionally, the hydrophobic and hydrophilic nature of the films were studied with the water contact angle (WCA) measurements. The $\mathrm{CdO}$ thin films showed cubic crystal phase diffraction peaks in the spectra. The surface of $\mathrm{CdO}$ thin films changed from prism-like morphology to network-like (nanofibrous) morphology with increasing concentration. The optical band gaps of thin films were calculated between 3.816-3.857 eV by Uv-Vis spectra. The Prisma- like morphology exhibited maximum transmittance above $65 \%$. Nature of the $\mathrm{CdO}$ thin film surface changed from hydrophobic to hydrophilic, depending on changing morphology with increasing the precursor concentration.
\end{abstract}

Keywords: Cadmium Oxide, Chemical Bath Deposition, the Effect of Concentration.

\section{Kimyasal Banyo Biriktirme Metodu ile hazırlanmış CdO İnce Filmlerin Yapısal, Morfolojik ve}

\section{Optik Özellikleri Üzerinde Molar Konsantrasyonu Etkisi}

ÖZET: Kadmiyum Oksit ( $\mathrm{CdO})$ ince filmler, farklı konsantrasyonlardaki solüsyonlar kullanılarak İndiyum Kalay Oksit (ITO) kaplamalı camlar üzerine Kimyasal Banyo Biriktirme (CBD) yöntemi ile sentezlenmiştir. $\mathrm{CdCl}_{2}$ 'nin sulu banyosunun konsantrasyonu $0.03 \mathrm{M}$ ile $0.05 \mathrm{M}$ arasında değişmektedir. Filmler $400{ }^{\circ} \mathrm{C}$ 'de 2 saat tavlanmıştır. CdO ince filmlerin yapısal, morfolojik ve optik özellikleri araştırılmıştır. Ek olarak, filmlerin hidrofobik ve hidrofilik yapısı, su temas açısı (WCA) ölçümleriyle çalışılmıştır. Bütün filmler kübik kristal yapıdan elde edilmiş, ancak ince filmlerin yüzey morfolojisi artan konsantrasyon ile, prizma benzeri yapılardan ağsı (nano lifli) yapılara dönüşmüştür. Optik bant boşluğu Uv-Vis spektrumları kullanılarak değerleri 3.816-3.857 eV aralığında hesaplanmıştır. Prizma benzeri morfoloji \%65 üzerinde maximum geçirgenlik göstermiştir. Konsantrasyonun artmasıyla, $\mathrm{CdO}$ ince filmlerin yüzey doğası, morfolojide meydana gelen değişikliklere bağlı olarak hidrofobik yapıdan hidrofilik yapıya dönüşmüştür.

Anahtar Kelimeler: Kadmiyum Oksit, Kimyasal Banyo Biriktirme, Konsantrasyon Etkisi

\footnotetext{
${ }^{1}$ Sibel MORKOÇ KARADENIZ (Orcid ID: 0000-0002-3215-1300), Department of Physics, Faculty of Arts and Sciences, Erzincan Binali Yıldırım University, Erzincan, Turkey

*Sorumlu Yazar: Sibel MORKOÇ KARADENIZ, e-mail: morkocsibel@gmail.com

Geliş tarihi / Received:05.10.2018

Kabul tarihi / Accepted 22.02.2019
} 


\section{INTRODUCTION}

$\mathrm{CdO}$ has used some applications due to having unique electrical and optical properties depending on vacancies and crystal structure such as wide bandgap (2.5 eV direct and 1.98 $\mathrm{eV}$ indirect), high transparency in the visible and near infrared rays (NIR) (Jung et al., 2014; Ahmed, 2017). It is one of TCO, II-IV group metal oxide semiconductor with FCC Bravais lattice cubic crystal structure which makes it similar to the $\mathrm{NaCl}$ crystal structure (Ahmed, 2017). CdO structures can be synthesized by several methods such as spin coating (Thambidurai et al., 2015), solvothermal synthesis (Ghosh and Rao, 2004), spray pyrolysis (Usharani et al., 2015), chemical bath deposition (Bulakhe and Lokhande, 2014). Among them, the CBD method is very easy, low cost, large area and repeatable technique (Morkoç Karadeniz et al., 2016).

In this paper, it was reported that thin films in form of $\mathrm{CdO}$ were synthesized by using simple CBD method at different precursor concentrations. Effect of the precursor concentration on structural, morphological and optical properties of the $\mathrm{CdO}$ thin films was investigated.

\section{MATERIALS AND METHODS}

In the present study, $\mathrm{CdO}$ thin films were grown on clean ITO substrates in the bath with 0.03, 0.04 and $0.05 \mathrm{M}$ concentration. The bath was prepared using Cadmium Chloride $\left(\mathrm{CdCl}_{2}\right)$, Ammonia Hydroxide $\left(\mathrm{NH}_{4} \mathrm{OH}-26 \%\right.$ $\mathrm{NH}_{3}$ in $\mathrm{H}_{2} \mathrm{O}$ ) chemical compounds and distilled water. After mixing $\mathrm{CdCl}_{2}$ and distilled water $(50 \mathrm{ml})$ for ten minutes, $\mathrm{NH}_{4} \mathrm{OH}$ was dropped slowly in the bath until getting a clear solution (9-10 pH). The ITO substrates were cleaned with methanol and deionized water in an ultrasonic cleaner for ten minutes respectively. Then, the substrates were dried at $100{ }^{\circ} \mathrm{C}$ for 1 hour in an air oven. The clean ITOs were immersed in the bath for 4 days at the room temperature. The as-deposited $\mathrm{Cd}(\mathrm{OH})_{2}$ films were dried at $100{ }^{\circ} \mathrm{C}$ for $15-20 \mathrm{~min}$. The reaction of CBD synthesis was given as follow;

$\mathrm{CdCl}_{2}+2 \mathrm{NH}_{4} \mathrm{OH} \longrightarrow \mathrm{Cd}(\mathrm{OH})_{2}+2 \mathrm{NH}_{4} \mathrm{Cl}$

Then, the samples were annealed at 400 ${ }^{\circ} \mathrm{C}$ for 2 hours to obtain the $\mathrm{CdO}$ thin films. The white $\mathrm{Cd}(\mathrm{OH})_{2}$ thin films converted to brown $\mathrm{CdO}$ thin films with an annealing process. The crystal structures of the films were studied using a Panalytical Empyrean XRay diffractometers (XRD) measurements operated at $45 \mathrm{kV}, 40 \mathrm{~mA}$ with $\mathrm{CuK} \alpha$ radiation $(\lambda=1.5406 \AA)$. The morphological properties of the films were studied using an FEI Inspect S50 Model Scanning Electron Microscopy (SEM). The optical properties of the thin films were studied using a PerkinElmer Lambda-35 Ultraviolet-Visible Spectrophotometer (UvVis) and the water contact angles of the thin films were observed using an Optical Tensiometer (Attension, Theta Lite) method.

\section{RESULTS AND DISCUSSION}

Figure 1 shows XRD patterns of the $\mathrm{CdO}$ thin films. The XRD peaks were in good agreement with the cubic $\mathrm{CdO}$ crystal system with (111) preferential orientation (Morkoç Karadeniz et al., 2016; Güney and İskenderoğlu, 2019). 


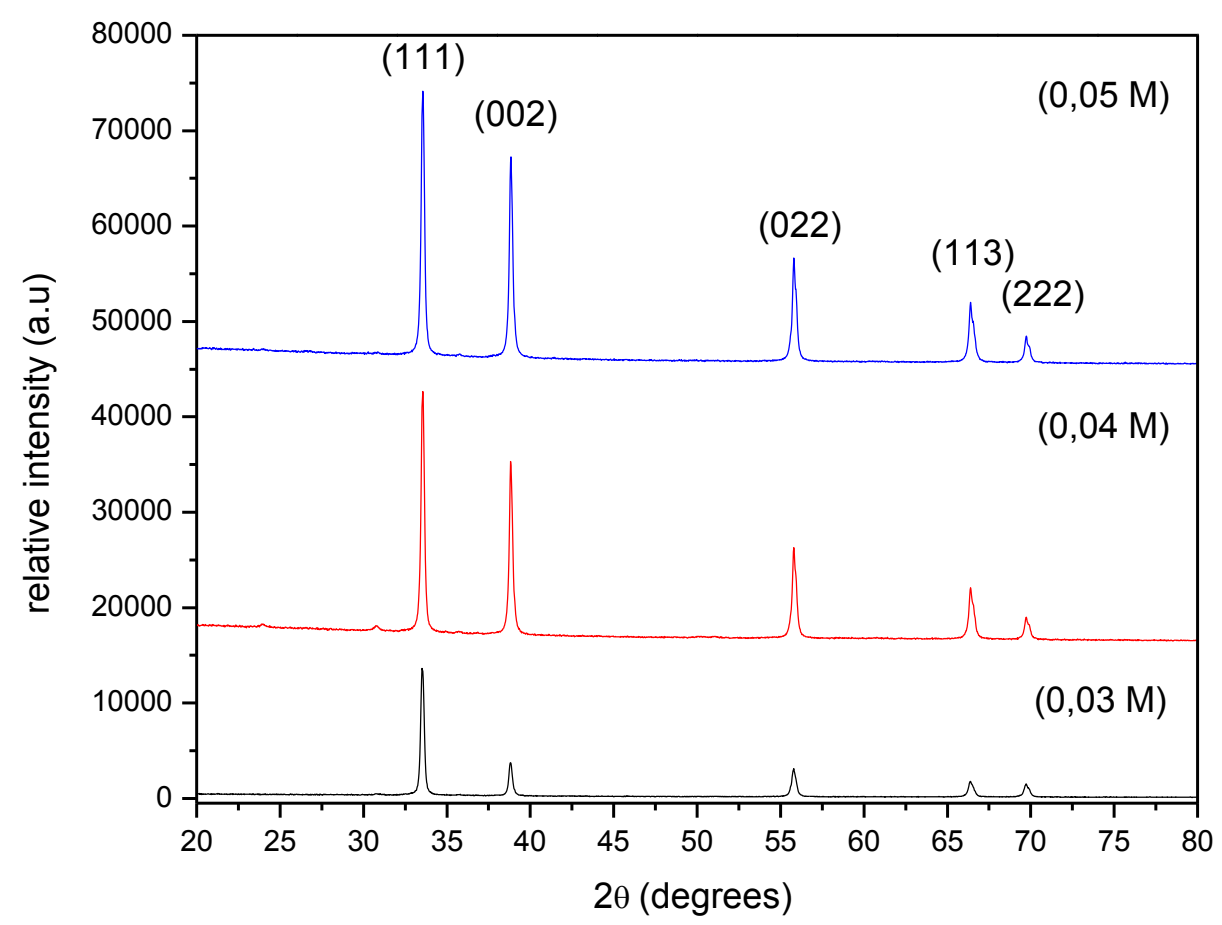

Figure 1. XRD spectra of the $\mathrm{CdO}$ thin films

The (002), (022), (113), (222) peaks also emerged in the fig.1 (JCPDS file No. 05-0640). The crystallinity of the thin film was improved with increasing concentration. The quantitative improvement in the crystallinity can be understood from the calculation of the grain size $(D)$ using Scherrer's formula is given as Equation 1;

$$
D=0.9 \lambda / \beta \cos \theta
$$

where $\lambda$ is the $\mathrm{x}$-ray wavelength $(1.5406$ $\AA$ for $\mathrm{CuK} \alpha), \theta$ is the diffraction angle and $\beta$ is the full width half maximum (FWHM). XRD parameters of the films are given in Table 1.

Table 1. XRD parameters of the $\mathrm{CdO}$ thin films

\begin{tabular}{cccccc}
\hline Concentration (M) & $\mathbf{2} \boldsymbol{\theta}^{\circ}$ & d-spacing $\AA$ & $\mathbf{a}(\AA)$ & FWHM & D (nm) \\
\hline 0.03 & 33.2224 & 2.69675 & 4.67077 & 0.205 & 42 \\
0.04 & 33.5141 & 2.67174 & 4.62745 & 0.183 & 47 \\
0.05 & 33.5185 & 2.67139 & 4.62648 & 0.178 & 48 \\
\hline
\end{tabular}




\begin{tabular}{lr}
\hline Sibel MORKOÇ KARADENIZ & Journal of the Institute of Science and Technology, 9(2): 847-854, 2019 \\
\hline Effect of Molar Concentration on Structural, Morphological and Optical Properties of CdO Thin Films Prepared by Chemical \\
Bath Deposition Method
\end{tabular}

Figure 2 shows SEM images of the $\mathrm{CdO}$ thin films. In previous studies, it was obtained $\mathrm{CdO}$ nanoplates for $0.1 \mathrm{M}$ concentration with $12 \mathrm{pH}$ on glass substrates (Bulakhe and Lokhande, 2014) and $\mathrm{CdO}$ nanolayers for 0.03 $\mathrm{M}$ concentration with 9-10 $\mathrm{pH}$ on ITO substrates (Morkoç Karadeniz et al., 2016) in the same bath for different conditions. In the present study, prism-like morphology with porous was obtained for $0.03 \mathrm{M}$ concentration in the bath. Then, network-like (nano-fibrous) structures were grown on the prism-like structures with increasing precursor concentration $(0.04 \mathrm{M})$. Distribution density of the $\mathrm{CdO}$ network-like (nano-fibrous) structures on the surface increased for $0.05 \mathrm{M}$ concentration. Although the morphology of the thin films changed with increasing solution concentration, preferential orientation of the crystal structure didn't change.

$\mathrm{Cd}(\mathrm{OH})_{2}$ ions get closer to each other to start the nucleation process in the bath, after nucleation of $\mathrm{Cd}(\mathrm{OH})_{2}$ molecules are aligned in one direction. Then, aggregated $\mathrm{Cd}(\mathrm{OH})_{2}$ ions merge into each other and finally, in stacking process, a collection of $\mathrm{Cd}(\mathrm{OH})_{2}$ molecules aggregates form prism-like morphology (Bulakhe and Lokhande, 2014). With increasing precursor concentration, the cadmium content in solution increases and saturate over the surface. Since the higher concentration causes higher viscosity and more complex structures, network-like (nanofibrous) agglomeration is formed.

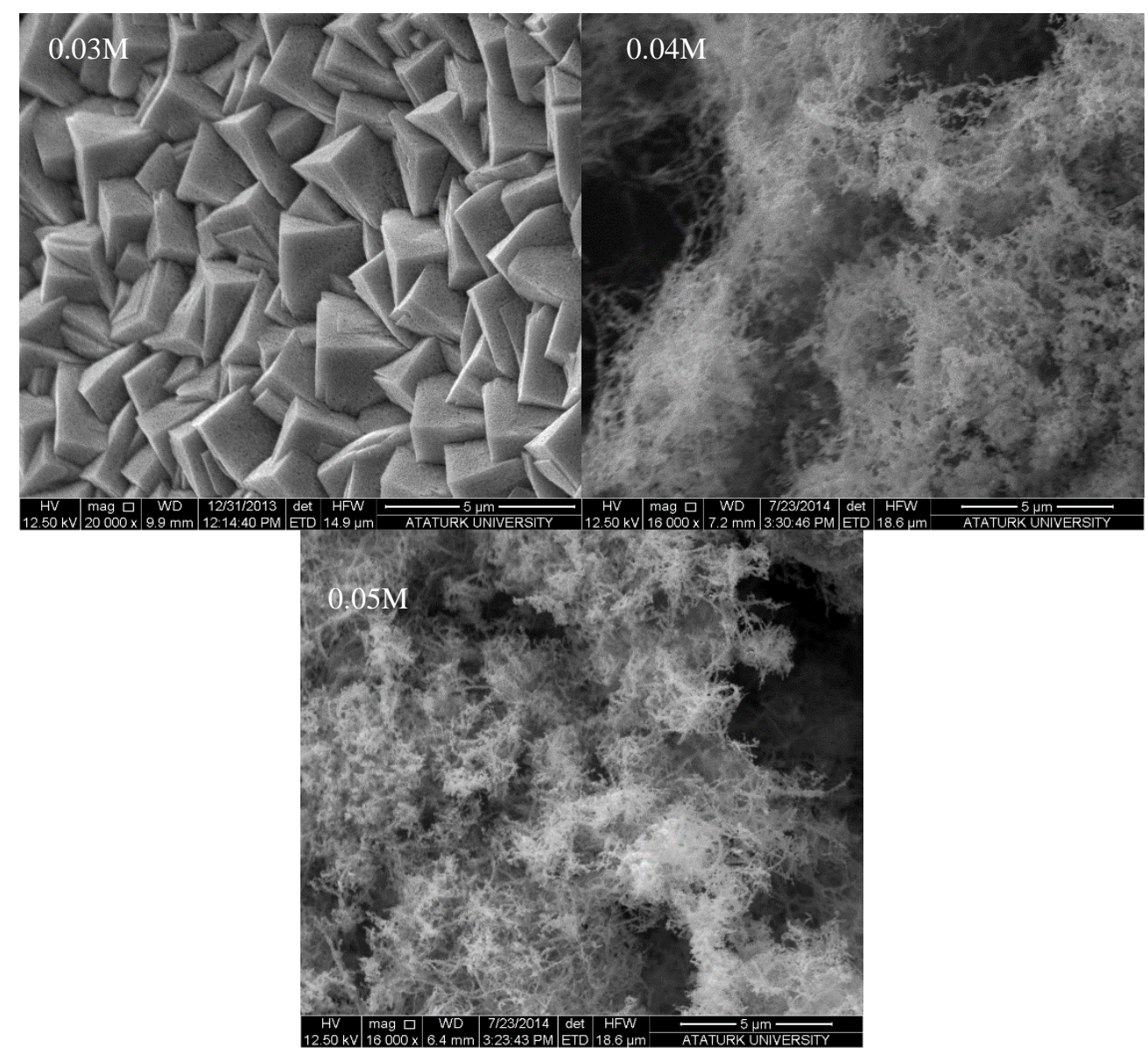

Figure 2. SEM images of the $\mathrm{CdO}$ thin films 
Prism-like $\mathrm{CdO}$ thin films can be used for solar cell applications as a TCO film if it has high transmittance value (Chala et al., 2015). Also, It is known that prism-like and network-like (nano-fibrous) $\mathrm{CdO}$ thin films can be used for gas sensor applications (Bulakhe and Lokhande, 2014; Salunkhe et al., 2008). It is reported that if the thickness of the film increases, gas sensor performance of the films increases (Chandiramouli and Jeyaprakash, 2013).

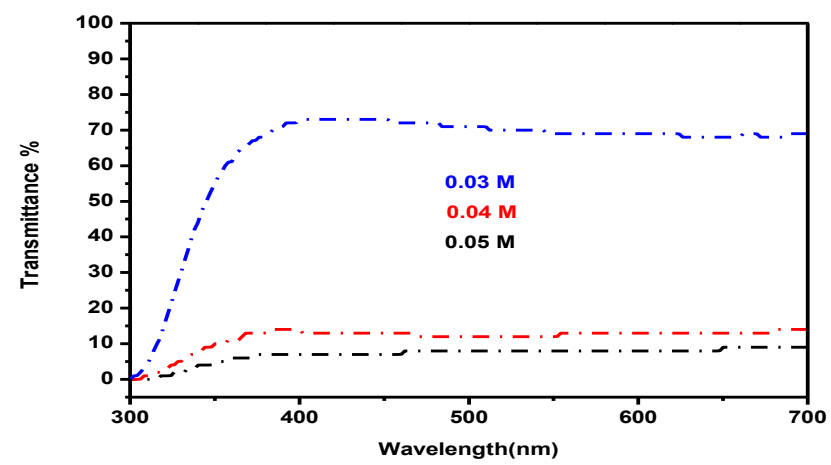

Figure 3 shows UV-Vis Transmittance (\% T) and Absorbance (A) spectra (Wavelength range in $300-700 \mathrm{~nm}$ ) of the $\mathrm{CdO}$ thin films. It was determined that the optical transmittance decreases, due to the increased film thickness of thin films. In the present study, $\mathrm{CdO}$ thin film which was grown on TCO substrate in the bath with $0.03 \mathrm{M}$ concentration, shows high transmittance (69\%). Therefore, it can be used solar cell applications (Chala et al., 2015).

Figure 3. Transmittance ( $\mathrm{T} \%$ ) and Absorbance (A) spectra of the $\mathrm{CdO}$ thin films

Figure 4 shows $(\alpha h v)^{2}$ versus $h v$ diagrams of the $\mathrm{CdO}$ thin films plotted by using Eqs. 2 and 3. Tauc Equation is given as Equation 2;

$\alpha h v=A\left(h v-E_{g}\right)^{n}$

where $h v$ is photon energy, it has been given as Equation 3;

$$
h v=1240 / \lambda
$$

The optical band gap $\left(E_{g}\right)$ was obtained using the linear part of the graph in figure 4 . The point which cuts $\mathrm{x}$-axis, that belongs to the linear part gives the $\mathrm{E}_{\mathrm{g}}$ values.

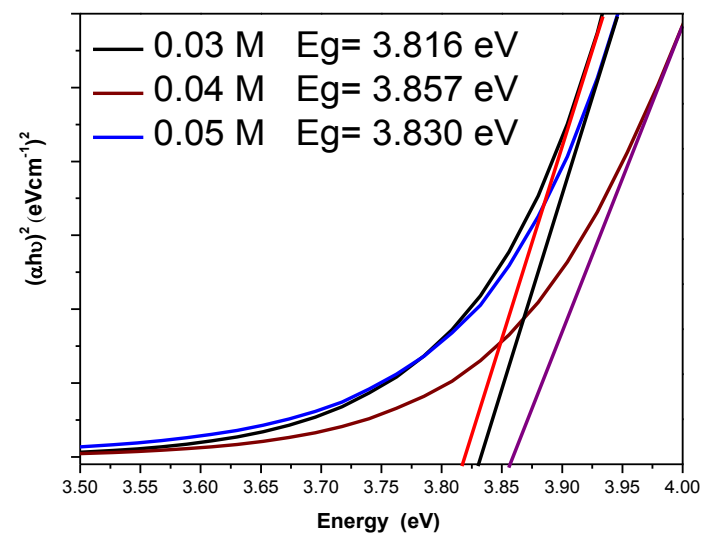

Figure 4. $(\alpha h v)^{2}$ vs. $\left.h v\right)$ spectra of the $\mathrm{CdO}$ thin films 
In this study, it was obtained higher optical band gaps than the bulk $\mathrm{CdO}$ band gap due to Burstein - Moss effects in the semiconductors (Yousefi et al., 2012). Approximate $\mathrm{T} \%$ and $\mathrm{E}_{\mathrm{g}}(\mathrm{eV})$ values of the $\mathrm{CdO}$ thin films were given in Table 2 .

Table 2. Transmittances ( $\mathrm{T} \%$ ) and Optical band gaps $\left(\mathrm{E}_{\mathrm{g}}\right)$ of the $\mathrm{CdO}$ thin films

\begin{tabular}{|c|c|c|}
\hline Concentration (M) & $\mathrm{T}(\%)(\lambda \sim 600 \mathrm{~nm})$ & $E_{g}(e V)$ \\
\hline 0.03 & 69 & 3.816 \\
\hline 0.04 & 13 & 3.857 \\
\hline 0.05 & 8 & 3.830 \\
\hline
\end{tabular}

Figure 5 shows WCA images of the $\mathrm{CdO}$ thin films. The chemical composition of the surface determines its surface energy: whereas surfaces rich in non-polar groups have low surface energies and, thus, are hydrophobic, surfaces with a high density of polar groups exhibit high surface energies and are hydrophilic. If the thin film has a hydrophobic nature, it shows less wettable. With regard to surface topography, an increase in the surface roughness enhances the surface hydrophobicity for the thin films (Jakaria et al., 2014).

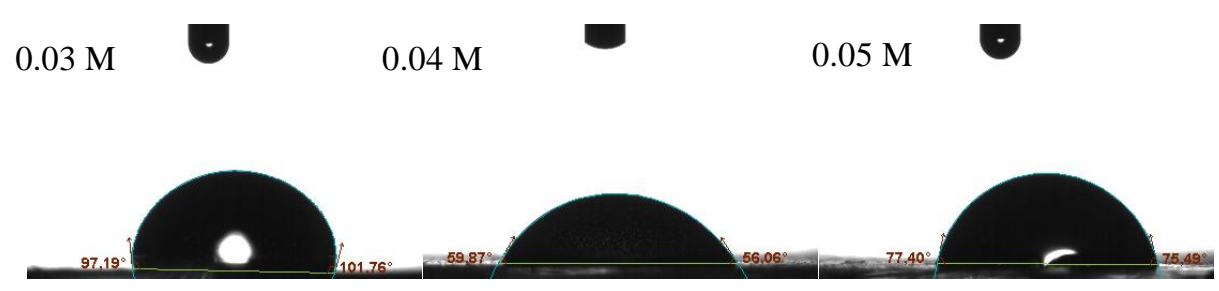

Figure 5. WCA images of the $\mathrm{CdO}$ thin films

If WCA of the film is larger than $90^{\circ}$, the structure becomes hydrophobic nature and if WCA of the film is smaller than $90^{\circ}$, the structure becomes hydrophilic nature (Myint et al., 2013). Also, the highly hydrophilic (WCA < $10^{\circ}$ ) coating can be desirable for some applications (Kenanakis et al., 2008).

It is known that thin films give a larger contact angle if they have a higher surface to volume ratio, smaller WCA indicates larger particles or the absence of a nanostructures on the surface of the substrate, the asymmetry exhibited by the angles is attributed to the irregular distribution of nanoparticles on the surface (Rashidzadeh et al., 2016). The Prismalike $\mathrm{CdO}$ structures had a larger contact angle because of their higher surface to volume ratio and the increasing concentration decreased their contact angle and lotus effect. The hydrophilic nature for network-like (nano-fibrous) structure is attributed to the irregular distribution of nanoparticles (agglomeration) on the surface of the substrate with increasing concentration. So, the $\mathrm{CdO}$ thin films lost hydrophobic nature with losing Prisma -like shapes of the nanostructures. Left, right, mean WCAs of the CdO thin films were given in Table 3 . 
Table 3. WCAs of the $\mathrm{CdO}$ thin films

\begin{tabular}{cccc}
\hline Concentration $(\mathbf{M})$ & \multicolumn{3}{c}{ Contact Angles $\left(\mathbf{C A}^{\circ}\right)$} \\
\cline { 2 - 4 } & Left & Right & Mean \\
\hline 0.03 & 96.91 & 101.56 & 99.24 \\
0.04 & 62.12 & 59.28 & 60.70 \\
0.05 & 77.84 & 76.10 & 76.97 \\
\hline
\end{tabular}

\section{CONCLUSION}

In this study, $\mathrm{CdO}$ thin films were grown by the CBD method at different precursor concentration. All of the $\mathrm{CdO}$ thin films showed a cubic crystal structure. The (111) peak intensity of the patterns increased with increasing concentration. As a function of increasing concentration, the prism-like morphology structures of the $\mathrm{CdO}$ thin films were coated with network-like (nano-fibrous) structures. The hydrophobic $\mathrm{CdO}$ prism-like structures with high transmittance $(69 \%)$ and wide optical band gap $(3.81 \mathrm{eV})$ is desirable as a TCO metal oxide for solar cell and gas sensor applications. Additionally, $\mathrm{CdO}$ thin films with nano-fibrous morphology can be used for LPG gas sensors due to high thickness.

\section{ACKNOWLEDGMENT}

Thanks to the research laboratory of Atatürk University for SEM microphotographs and thank to the research laboratories of Erzincan Binali Yıldırım University for other characterization techniques.

\section{REFERENCES}

Ahmed HH, 2017. Variation of the structural, optical and electrical properties of CBD $\mathrm{CdO}$ with processing temperature. Materials Science in Semiconductor Processing, 66:215-222.
Bulakhe RN, Lokhande CD, 2014. Chemically deposited cubic structured $\mathrm{CdO}$ thin films: Use in liquefied petroleum gas sensor.Sensors and Actuators B: Chemical, 200:245-250.

Chala S, Sengouga N, Yakuphanoglu F, 2015. Modeling the effect of defects on the performance of an $\mathrm{n}-\mathrm{CdO} / \mathrm{p}-\mathrm{Si}$ solar cell. Vacuum, 120:81-88.

Chandiramouli R, Jeyaprakash BG, 2013. Review of $\mathrm{CdO}$ thin films. Solid State Sciences, 16: 102-110

Ghosh M, Rao CNR, 2004. Solvothermal synthesis of $\mathrm{CdO}$ and $\mathrm{CuO}$ nanocrystals. Chemical Physics Letters, 393:493-497.

Güney H, İskenderoğlu D, 2019. The effect of $\mathrm{Zn}$ doping on $\mathrm{CdO}$ thin films grown by SILAR method at room temperature. Physica B: Condensed Matter, 55:119-123

Jakaria A, Kateryna B, Michael O, Mohan VJ, 2014. Wetting, Solubility and Chemical Characteristics of Plasma-Polymerized 1Isopropyl-4-Methyl-1,4-Cyclohexadiene Thin Films. Coatings, 4:527-552

Jung Y, Baek SH, Park JI, 2014. Controllable deposition of cadmium oxide and hydroxide nanostructures on silicon using a hydrothermal method. Journal of Alloys and Compounds, 595:46-50. 
Kenanakis G, Stratakis E, Vlachou K, Vernardou D, Koudoumas E, Katsarakis N, 2008. Light-induced reversible hydrophilicity of $\mathrm{ZnO}$ structures grown by aqueous chemical growth. Applied Surface Science, 254: 5695-5699.

Morkoç Karadeniz S, Kılınç T, Bozkurt Çırak B, Irmak Sakaoğlu T, Çırak Ç, Ertuğrul M, Ekinci A.E, 2016. Structural, Morphological and Optical Properties of Well-Ordered $\mathrm{CdO}$ nanostructures Synthesized by Easy-Economical Chemical Bath Deposition Technique. Spectroscopy and Spectral Analysis, 36:1998-2000.

Myint MTZ, Kumar NS, Hornyak GL, Dutta J, 2013. Hydrophobic/hydrophilic switching on zinc oxide micro-textured surface. Applied Surface Sciences, 264: 344-348.

Rashidzadeh M, Carbajal-Franco G, TiburcioSilver A, 2016. Hydrophobic Coatings Composed by Cubic-Shaped $\mathrm{CdO}$ Nanoparticles Grown by a Novel and Simple Microwave Method. Journal of Nanoparticles, 2016:1-6.
Salunkhe RR, Shinde VR, Lokhande CD, 2008. Liquefied petroleum gas (LPG) sensing properties of nanocrystalline $\mathrm{CdO}$ thin films prepared by chemical route: Effect of molarities of precursor solution. Sensors and Actuators B, 133:296-301

Thambidurai M, Muthukumarasamy N, Ranjitha A, Velauthapillai D, 2015. Structural and optical properties of Ga-doped $\mathrm{CdO}$ nanocrystalline thin films. Superlattices and Microstructures, 86:559-563.

Usharani K, Balun AR, Nagarethinam VS, Suganya M, 2015. Characteristic analysis on the physical properties of nanostructured $\mathrm{Mg}$-doped $\mathrm{CdO}$ thin films-Doping concentration effect. Progress in Natural Science: Materials International, 25: 251-257.

Yousefi R, Jamali-Sheini F, Khorsand ZA, Mahmoudian MR, 2012. Effect of indium concentration on morphology and optical properties of In-doped $\mathrm{ZnO}$ nanostructures. Ceramics International, 38:6295-6301 